\title{
DETECTION OF TESTICULAR CANCER IN MEN PRESENTING WITH INFERTILITY
}

Fabio Firmbach Pasqualotto, Eleonora Bedin Pasqualotto, Ashok Agarwal and Anthony Joseph Thomas Jr.

PASQUALOTTO FF et al. - Detection of testicular cancer in men presenting with infertility. Rer. Hosp. Clín. Fac. Med. S.

Paulo 58(2):75-80, 2003.

PURPOSE: Infertility is one of the less common presenting features associated with testicular tumors. We evaluated the histologic and biochemical findings, and pregnancy outcome in patients presenting with infertility who were found to have testicular tumors.

METHODS: Seven patients with infertility were found to have testicular cancer over a 15-year period. All patients had a testicular ultrasound evaluation. The indications for the ultrasound were testicular pain in 2 patients, suspicious palpable mass in 4 , and to rule out the presence of germ cell neoplasia in a patient with carcinoma in situ detected on a previous biopsy. Physical exam, histological findings, hormonal levels, tumor markers, and pregnancy outcome results were recorded from the patients medical charts.

RESULTS: Two men had elevated serum follicle stimulant hormone and luteinizing hormone levels, 1 of them had an abnormally low serum testosterone level. Tumor markers were normal in all patients. In 4 patients the tumor was on the right side and in 3 on the left. The histological diagnoses were seminoma $(\mathrm{n}=5)$, Leydig cell tumor $(\mathrm{n}=1)$, and carcinoma in situ $(n=1)$. Of the 7 patients, 5 underwent adjuvant radiation therapy. Two patients had sperm cryopreserved. Follow up on fertility status was available in 6 cases. One patient has established a pregnancy and 5 did not achieve a pregnancy after treatment for their cancer.

CONCLUSIONS: Most of the men who have testicular cancer and male infertility have a seminona. Therefore, men who present with infertility should be thoroughly investigated to rule out such serious, concomitant diseases along with their infertility.

DESCRIPTORS: Fertility evaluation. Male infertility. Testis cancer. Testicular neoplasia.

\section{INTRODUCTION}

The incidence of testicular cancer has increased all over the world during the last 4 to 5 decades, and in industrialized countries, testicular tumors are the most common malignant disease among men aged 20 to 34 years ${ }^{1,2}$. While the etiologic causes of testicular cancer are unknown, a number of risk factors have been identified including in situ carcinoma or invasive carcinoma of the contralateral testis, cryptorchidism, testicular dys- genesis, and subfertility ${ }^{3-7}$.

A number of reports have suggested a direct correlation between testicular cancer and infertility ${ }^{8,9}$. Although a significant number of cancer patients present with poor pretreatment semen quality, the incidence of oligospermia or azoospermia in these

From the Center for Advanced Research in Human Reproduction and Infertility, Urological Institute, Cleveland, EUA. Received for publication on June 10, 2002. patients remains unknown ${ }^{8,9}$. Physical and mental stress, genetic factors, and hormonal imbalances may all impair spermatogenesis ${ }^{2,10-12}$. As survival rates improve, the effect of aggressive therapy on fertility becomes more apparent ${ }^{13}$.

Little is known about the incidence, histological features and fertility outcome of testicular cancer in men who present for infertility evaluation. The purpose of the study was to assess the histologic and biochemical findings, and pregnancy outcome in pa- 
tients undergoing infertility evaluation who were incidentally diagnosed with testicular tumors.

\section{MATERIALSAND METHODS}

From 1983-1998, 7 men were found to have undergone infertility evaluations and were diagnosed as having concurrent testicular cancers. A specialist in male infertility (AJT) examined all patients. Five men had primary, and two had secondary infertility. Of the 7 patients presenting for fertility evaluation, 2 also had testicular pain, 1 had history of bilateral cryptorchidism and 2, unilateral cryptorchidism. One patient underwent a previous orchiectomy due to an undescended testis. Semen analyses were performed on all patients at the first appointment. All patients underwent a radical orchiectomy. Demographic data, histological findings, hormonal status, tumor markers, and pregnancy outcome results were recorded from their medical charts.

\section{RESULTS}

The mean age of the patients at the time of diagnosis was 30.7 years (range 25-34) (Table 1). Semen analysis was evaluated according to the World Health Organization (WHO) criteria ${ }^{14}$. Semen analysis revealed oligoasthenospermia in 3 patients, azoospermia in 2, oligospermia in 1, and asthenospermia in 1 . All patients had a testicular ultrasound evaluation that demonstrated a hypoechoic lesion or irregular intratesticular mass. The only exception was a man with a previous diagnosis of carcinoma in situ, whose ultrasound revealed no abnormality. The indications for ultrasound were testicular pain in 2 patients, suspicious palpable mass in 4 , or rule out the presence of invasive germ cell neoplasia in a patient with carcinoma in situ diagnosed at a previous testicular biopsy.

Hormonal status and tumor markers were available in all patients. Two men had elevated serum follicle stimulant hormone (FSH) and luteinizing hormone $(\mathrm{LH})$ at the time of fertility evaluation, and 1 of them had abnormally low serum testosterone levels. One of these patients had undergone prior orchiectomy for undescended testis, and the other patient had an atrophic testis contralateral to the testis with cancer. Alpha-feto-protein (AFP), and human chorionic gonadotropin subunit B (B-HCG) were normal in all men.

In 4 patients, the tumor was located in the right testis, and in 3, the left (Table 2). In the 3 patients who underwent orchidopexy due to cryptorchidism, the cancer was present in the orchidopexed testis in 2 patients, and in the contralateral testis in 1 . The pathologic specimen showed invasive germ cell tumors in 6 patients and intratubular germ cell neoplasia (carcinoma in situ) in 1 . All the invasive germ cell tumors were pT1. The histological diagnosis of the surgical specimen showed seminoma in 5 patients, Leydig cell tumor in 1 , and carcinoma in situ in 1.

Of the 7 patients, 5 were also treated with adjuvant radiation therapy

Table 1 - Age, symptoms and hormonal assessment in patients with infertility and testicular cancer.

\begin{tabular}{|c|c|c|c|c|c|c|c|c|}
\hline $\mathrm{N}$ & Age & Symptoms & Semen characteristics & AFP & B HCG & FSH & $\mathrm{LH}$ & Testosterone \\
\hline 1 & 33 & Infertility & oligoasthenospermia & 2.5 & 2.5 & 4.5 & 6.5 & 532 \\
\hline 2 & 27 & Infertility & oligospermia & 3 & 2.5 & 3 & 5.5 & 528 \\
\hline 3 & 34 & Infertility & oligoasthenospermia & 2.3 & 3.5 & 33 & 25 & 138 \\
\hline 4 & 32 & Infertility & asthenospermia & 3.2 & 4.5 & 5 & 6 & 350 \\
\hline 5 & 33 & Testis pain, infertility & oligoasthenospermia & 1.2 & 2.5 & 9 & 5.5 & 481 \\
\hline 6 & 25 & Testis pain, infertility & azoospermia & 1.5 & 4.5 & 22 & 15 & 358 \\
\hline 7 & 31 & Infertility & azoospermia & 1.5 & 3 & 9.5 & 3.2 & 450 \\
\hline
\end{tabular}

Table 2 - Histological type of cancer, and pregnancy outcome in patients with infertility and testicular cancer.

\begin{tabular}{lllll}
\hline $\mathrm{N}$ & Testis & Ultrasound & Pathology & Adjuvant Therapy \\
\hline 1 & Right & Small intratesticular mass & Seminoma & Radiation therapy \\
2 & Right & Hypoechoic mass & Seminoma & Radiation therapy \\
3 & Right & Multiple hypoechoic mass & Seminoma & Radiation therapy \\
4 & Left & Hypoechoic mass & Seminoma & Radiation therapy \\
5 & Right & Hypoechoic irregular mass & Seminoma & Radiation therapy \\
6 & Left & Hypoechoic mass & Leydig cell tumor & 0 \\
7 & Left & No mass & Ca in situ & ? \\
\hline
\end{tabular}


to the para-aortic and ipsilateral common iliac lymph nodes. All of these men had a histologic diagnostic of seminoma. The other 2 patients underwent radical orchiectomy alone.

Only 2 patients had sperm cryopreserved before radiation therapy. Both patients who cryopreserved their semen attempted pregnancies with the use of assisted reproductive techniques (ART), but only one succeded. The remaining 4 patients who tried to impregnate their wives through sexual intercourse alone did not succeed. For 1 patient, the follow up on fertility status was not available.

\section{DISCUSSION}

In the last 30 years, there has been increased research on testicular germ cell cancers ${ }^{7,15}$. For all countries, the incidence showed a substantial upward trend during the period of observation. The annual increase varied from $2.3 \%$ in Sweden to $5.2 \%$ in former East Germany. If this trend were to continue, it is postulated that the overall incidence of testicular cancer would double every 15-25 years. Unlike most cancers that primarily affect the elderly, germ cell tumors exhibit a small post-natal peak and a major peak in the 20-45 year range ${ }^{16}$. The majority of these patients are in their reproductive years and may not have started or completed their families ${ }^{12,16}$.

Many studies concerning patients with testicular cancer indicates that the majority of them have poor semen quality before radical orchiectomy ${ }^{2,17}$. It is well documented that testicular cancer is associated with impaired spermatogenic function and some patients already have impairment of Leydig cell function before orchiectomy. Approximately $50 \%$ of patients with germ cell tumors have sperm concentration below $10 \times 10^{6} / \mathrm{mL}$, whereas the median sperm concentration in the general population is expected to be $50 \times 10^{6} / \mathrm{mL}$ or higher ${ }^{10}$.

The association between testicular cancer and poor gonadal function is very interesting from both an etiologic and therapeutic point of view ${ }^{2,10}$. First, the increase in the incidence of testicular cancer has been suggested to be associated with a general decline in male reproductive health and it seems likely that the development of testicular cancer shares common etiological factors with other types of testicular dysfunction. This is supported by the observation that men with various types of gonadal dysfunction such as testicular dysgenesis, androgen insensitivity syndrome, and cryptorchidism have an increased risk of testicular cancer $5,7,15,18-20$. In our data, even though 3 patients had cryptorchidism, 4 did nor have it. Therefore, it might be possible that the 3 patients with cryptorchidism developed testicular cancer due to the presence of cryptorchidism. From a therapeutic prospective, because the cure rate in patients with testicular cancer exceeds $90 \%$, fertility aspects need to be addressed in the management of these men ${ }^{2,11}$.

We assessed patients who presented with infertility and were ultimately diagnosed as having testicular cancer. Infertility is one of the less common presenting features of testicular cancer. The possibility that infertility may affect men at high risk for testicular neoplasia was first suggested by Skakkebaek, who described the finding of carcinoma in situ (CIS) in testicular biopsies from 2 infertile men who later developed germ cell tumors 7. In a further study, Skakkebaek et al. reported CIS in 9 infertile patients, 4 of whom developed invasive tumors within 5 years ${ }^{21}$. The incidence of CIS in infertile men has been reported as $0.4 \%$ to $1.1 \%$. It is estimated that an invasive growth will develop in $50 \%$ of patients within 5 years of the diagnosis $9,18,20$. The interval between the detection of carcinoma in situ and the diagnosis of an invasive carcinoma range from 6 months to 9 years. The types of invasive tumors that can develop include seminoma, embryonal carcinoma, and teratocarcinoma.

A previous report found an incidence of 230/100,000 cases of testicular cancer in men seeking infertility evaluation, higher than that of the agematched population $(6.74 / 100,000){ }^{9}$. In the past years, we diagnosed testicular cancer in 6 patients, and carcinoma in situ in 1 patient who presented for fertility evaluation. We cannot evaluate the incidence of testicular cancer in infertile men due to the difficulty in assessing the number of patients who sought fertility treatment during this period of time. The semen analysis of these patients at the time of presentation revealed oligoasthenospermia in 3, azoospermia in 2, asthenospermia in 1 , and oligospermia in 1 . Therefore, all patients had at least one abnormality in their semen analysis contributing to their infertility.

Testicular microlithiasis (TM) has been considered a benign, non-progressive condition but recent reports have demonstrated the association between TM and testicular malignancy ${ }^{22-24}$. Although the clinical significance of TM and the importance of ultrasound screening for this condition have not been defined, $30 \%$ to $45 \%$ of all reported patients with TM had associated testicular malignancies. In our patient population, however there were no patients with microlithiasis diagnosed with testicular ultrasound.

In our group of patients, all men underwent a radical orchiectomy. The pathologic specimen revealed 6 cases at stage pT1, and 1 CIS, demonstrating that all tumors were treated at an early stage. Of the 7 patients, 5 had seminoma, 1 had Leydig cell tumor, and 1 had carcinoma in situ. Although the management of testicular cancer is well described, the role of orchiectomy 
in CIS is still debatable. On the other hand, $50 \%$ of men with CIS will develop invasive germ cell cancer. Therefore, we considered very important to include in our list of patients with testicular cancer, the 1 with carcinoma in situ. All 5 patients with seminoma underwent adjuvant radiation therapy.

Pierek et al. assessed the role of scrotal ultrasound in the evaluation of male infertility and found 7 cases of testicular cancer out of 1,372 subfertile men ${ }^{25}$. In their series, 5 patients had Leydig cells tumor and 2 had seminoma. In our center, ultrasound is not used routinely to screen subfertile men. The indications for scrotal ultrasonography were testicular pain or abnormalities in the physical examination.

Only 2 of our patients chose to freeze their sperm. It is important to note that some of these patients underwent their fertility evaluation more than 10 years ago, at a time when there were not available the assisted reproductive techniques (ART) such as in vitro fertilization (IVF) with intracytoplasmic sperm injection (ICSI). Among the 6 patients in whom follow up was available, 1 achieved a pregnancy with ICSI. The remaining 5 never achieved a pregnancy either through natural intercourse or ART.

It is important, therefore, that all men with infertility undergo thorough evaluation to rule out such a serious concomitant condition. While all of our patients were treated at an early stage, it remains to be seen when these patients would have been diagnosed with testicular cancer if they had not been appropriately evaluated. In the era of ART, when some men are only asked to give a semen sample and never examined, this issue cannot be overemphasized. It is imperative to obtain a careful history and perform a thorough physical examination for all infertile men, irrespective the semen analysis.

In summary, all 7 of our patients had an abnormal semen analysis prior to being diagnosed with testicular cancer, and 6 of 7 had abnormal finding related to their testicular examination. Seminomas were the most prevalent tumors seen. Men presenting for infertility investigation should be thoroughly evaluated to detect other potentially life-threatening conditions.

\section{RESUMO}

PASQUALOTTO FF e col. - Detecção de câncer de testículo em homens com infertilidade. Rev. Hosp. Clín. Fac. Med. S. Paulo 58(2):75-80, 2003.

PROPÓSITO: Infertilidade é um dos padrões incomuns associados com tumores de testículo. Nós avaliamos os achados histológicos, bioquímicos, e gravidez em pacientes com infertilidade nos quais foram detectados tumores de testículo.

MÉTODOS: Sete pacientes com infertilidade nos quais câncer de testí- culo foi detectado em um período acima de 15 anos. Todos os pacientes foram avaliados com ultra-sonografia. As indicações para ultra-sonografia foram dor testicular em dois pacientes, suspeita de massa palpável em quatro, e descartar a presença de neoplasia de células germinativas em um paciente com carcinoma in situ detectado em biópsia prévia. Exame físico, achados histológicos, níveis hormonais, marcadores tumorais, e resultados de gravidez foram avaliados nos prontuários dos pacientes.
RESULTADOS: Dois homens tinham níveis séricos elevados de hormônio folículo-estimulante e hormônio luteinizante; um destes tinha níveis anormalmente baixos de testosterona. Marcadores tumorais estavam normais em todos os pacientes. Em quatro pacientes, o tumor estava localizado no testículo direito e em três no esquerdo. Os diagnósticos histológicos foram seminoma $(\mathrm{n}=5)$, tumor de células de Leydig $(\mathrm{n}=1)$ e carcinoma in situ $(\mathrm{n}=$ $1)$. Dos sete pacientes, cinco foram submetidos à radioterapia. Dois pacientes 
congelaram seus espermatozóides. Acompanhamento no estado de fertilidade estava disponível em seis pacientes. Um paciente estabeleceu gravidez e cinco não conseguiram engravidar após tratamento do câncer.
CONCLUSÕES: A maioria dos homens com câncer de testículo e infertilidade possui um seminoma. Homens que se apresentam com infertilidade devem ser cuidadosamente investigados para descartar doenças concomitantes e sérias juntamente com a infertilidade.

DESCRITORES: Avaliação da fertilidade. Infertilidade masculina. Câncer de testículo. Neoplasia de testículo.

\section{REFERENCES}

1. ADAMI H, BERGSTROM R, MOHNER M et al. - Testicular cancer in nine northern European countries. Int $\mathbf{J}$ Cancer 1994;59:33-38.

2. TUREK PJ, LOWTHER DN, CARROLL PR - Fertility issues and their management in men with testis cancer. Urol Clin North Am 1998;25:5217-31.

3. BERTHELSEN JG, SKAKKEBAEK NE - Gonadal function in men with testis cancer. Fertil Steril 1983;39:68-75.

4. DIECKMANN KP, LOY V, BUTTNER P - Prevalence of bilateral testicular germ cell tumors and early detection based on contralateral testicular intra-epithelial neoplasia. Br J Urol 1993;71:340-345.

5. GIWERCMAN A, BRUUN E, FRIDMODT-MOLLER C et al. Prevalence of carcinoma in situ and other histopathological abnormalities in testes of men with a history of cryptorchidism. J Urol 1989;142:998-1001.

6. HARLAND SJ, COOK PA, FOSSA SD et al. - Intratubular germ cell neoplasia of the contralateral testis in testicular cancer: defining a high risk group. J Urol 1998;160:1353-1357.

7. SKAKKEBAEK NE Carcinoma in situ of the testis: frequency and relationship to invasive germ tumors in infertile men. Histopathology 1978;2:157-170.

8. PRYOR JP, CAMERON KM, CHILTON CP et al. - Carcinoma in situ in testicular biopsies from men presenting with infertility. BJU 1983;55:780-784.
9. LOGARAKIS NF, BEDARD Y, ZINI A et al. - High incidence of testicular tumors in infertile men. ASRM, 1998, San Francisco.

10. PETTERSEN MP, SKAKKEBAEK NE, GIWERCMAN A Gonadal function in men with testicular cancer: Biological and clinical aspects. APMIS 1998;106:24-36.

11. PONT J, ALBRECHT W - Fertility after chemotherapy for testicular germ cell cancer. Fertil Steril 1997;68:1-5.

12. HALLAK J, HENDIN BH, THOMAS Jr. AJ et al. - Investigation of fertilizing capacity of cryopreserved spermatozoa from patients with cancer. J Urol 1998;159:1217-1220.

13. AGARWAL A, TOLENTINO MV, SIDHU RS et al. - Effect of cyropreservation on semen quality in patients with testicular cancer. Urol 1995;46:382-389.

14. WORLD HEALTH ORGANIZATION (WHO) - Laboratory manual for the examination of human spermatozoa and semencervical mucus interaction. $4^{\text {th }}$ Cambridge: Cambridge University Press, 1999. [13].

15. SKAKKEBAEK, NE, MEYTS ER-DE, JOERGENSEN N et al. Germ cell cancer and disorders of spermatogenesis: An environmental connection? APMIS 1998;106:3-12.

16. OESTERLIND A - Diverging trends in incidence and mortality of testicular cancer in Denmark, 1943-1982. Br J Cancer 1986;53:501-505. 
17. BOTCHAN A, HAUSER R, YOGEV L et al. - Testicular cancer and spermatogenesis. Hum Reprod 1997; 12:755-758.

18. CORTES D, THORUP J, FRISCH M et al. - Examination for intratubular germ cell neoplasia at operation for undescended testis in boys. J Urol 1994;151:722-725.

19. FORD F, PARKINSON MC, PRYOR JP - The undescended testis in adult life. Br J Urol 1985;57:181-184.

20. KLIESCH S, BERGMANN M, HERTLE L et al. - Semen parameters and testicular pathology in men with testicular cancer and contralateral carcinoma in situ or bilateral testicular malignancies. Hum Reprod 1997;12:2830-2835.

21. SKAKKEBAEK NE, BERTHELSEN JE - Carcinoma in situ of the testis and invasive growth of different types of germ cell tumours. A revised germ cell theory. Int J Androl 1981;4:2634.
22. GANEM JP, WORKMAN KR, SHABAN S - Testicular microlithiasis is associated with testicular pathology. Urology 1999;53:209-213.

23. KESSARIS DN, MELLINGER BC - Incidence and implication of testicular microlithiasis detected by scrotal duplex sonography in a select group of infertile men. J Urol 1994;152:15601561 .

24. PARRA BL, VENABLE DD, GONZALES E et al. - Testicular microlithiasis as a predictor of intratubular germ cell neoplasia. Urology 1996;48:797-799.

25. PIERIK FH, DOHLE GR, VAN MUISWINKEL JM et al. - Is routine scrotal ultrasound advantageous in infertile men? J Urol 1999;162:1618-20. 